The $5^{\text {th }}$ International Conference on Family Business and Entrepreneurship

\title{
IMPACT OF DIGITAL LITERACY AND MARKET ORIENTATION THROUGH E-COMMERCE ADOPTION ON THE MSME PERFORMANCE MODERATED BY O2O BUSINESS ADOPTION
}

\author{
Umi Suryani $^{{ }^{*} \text {, Sri Bramantoro }}{ }^{2}$, Mts. Arief ${ }^{3}$, M. Hamsal ${ }^{4}$ \\ 1,2,3,4 Faculty of Business, Binus University, Corresponding author: umi.suryani@binus.ac.id
}

\begin{abstract}
This study aims to examine the influence of digital literacy and market orientation on MSME performance mediated by E-commerce adoption with O2O Business as a Moderating variable. The population in this study are all MSMEs that have collaborated with E-Commerce. The sample in this study was obtained using a quota sampling technique, which only limited data acquisition to 100 MSMEs of ECommerce partners. Data is obtained by distributing questionnaires to respondents through online. The collected data is then analysed using Path analysis assisted by the Smart PLS application. The result shows that Digital Literacy and Market Orientation have a significant positive effect on E-Commerce Adoption, then ECommerce Adoption, Market Orientation and Digital Literacy have a significant positive effect on Performance MSMEs, Digital Literacy, Market Orientation and E-commerce adoption has a significant positive effect on MSME Performance moderated by $\mathrm{O} 2 \mathrm{O}$ Business Adoption. Understanding of market orientation and digital literacy in running a business can have an impact on customer satisfaction which then has an impact on improving MSME performance. Researchers who want to review the topic in this study can conduct a correlation test on a larger scale to get a more detailed picture of the impact of digital literacy and market orientation on MSMEs and other sectors.
\end{abstract}

Keywords: digital literacy, market orientation, e-commerce adoption, O2O adoption, MSME performance.

\section{Introduction}

The target of the national entrepreneurship ratio in the National Medium-Term Development Plan (RPJMN)is to reach 3.9\% and the growth of new entrepreneurs is 4\% in 2024. MSMEs are the most important pillars in theIndonesian economy. Based on data from the Ministry of Cooperatives and SMEs, the number of MSMEs currently reaches 64.2 million with a contribution to GDP of $61.07 \%$ or worth 8,573.89 trillion rupiah (TUC \&childer ENgland., 2016). The contribution of MSMEs to the Indonesian economy includes the ability to absorb $97 \%$ of thetotal workforce and can collect up to $60.4 \%$ of the total investment. However, the high number of MSMEs in Indonesia is also inseparable from the existing challenges (Hill, 2018).

To answer this challenge, the government has implemented a number of MSME support programs, includingincentive and financing assistance through the PEN program, People's Business Credit, the Proudly Made in Indonesia National Movement (Lin, 2018), Digitalization of MSME marketing, strengthening alumni entrepreneurs of the Pre-Employment Card Program through KUR Financing, and including a long-term strategyto raise the MSME class through the Job Creation Law (Gunawan, 
M., Asyahira, R., \& M Sidjabat, 2020). Apart from government support, the existence of MSMEs can be done by increasing brand concept, seize market share, and interact with customers at the right time to gain growth momentum in the new economic environment. Every organization that carries out business activities will also have the hope of having good and increasing performance so that the goals of MSMEs will be achieved. Currently, cultural or lifestyle shifts that occur in society also affect product marketing carried out by MSMEs, a lifestyle that is more internet-oriented makes many businesses move from conventional sales to digital (Charoensukmongkol, P., \& Sasatanun, 2017a). From year to year, the number of internet users increases and Indonesia is one of the countries with the largest number of internet users in the world. The development of the internet has the potential to develop the e-commerce market in the future. The development of internet users, online shoppers and sellers who use e-commerce is increasing every year. It is an opportunity for MSMEs to exist a need for a liaison between MSME actors, and the development of the internet to maximizeMSME business.

As a business, MSMEs are required to be able to understand and evaluate the information they receive. The ability to receive information is of course also balanced with the ability to trace and identify the information received, especially in digital form or what is called digital literacy ability where digital literacy is the ability to understand information, and more importantly to evaluate and integrate information in various formats that can beprovided by computers in (Gilster, M. E., Kleinschmit, J. L., Cummings, S. P., \& Ronnenberg, 2020). Digital literacy can also be called the use of the internet as the first reference to find information and can also be said as a person's ability to use the internet as a medium in finding information. Therefore, business actors, especially small-scale businesses, have digital literacy skills as a goal to develop businesses and develop the community's economy for business actors.

Changes in the business environment such as: globalization, trade liberalization, technological developments, deregulation and other changes have had an impact on customers (customers), and competition (competition) (Anand, S., \& Rao, 2016) changes in consumer markets are characterized by customers who are increasingly educated and increasingly critical, customers become very picky (choosy), customers who determine the products and services needed, customers demand individual treatment. On the other hand, an MSME is required to create market opportunities. An MSME must be able to retain its customers or even try to seize the competitor's MSME marketin order to maintain its existence in the midst of increasingly intense competition. The ability of MSMEs to understand consumer wants and needs and provide products or services that consumers want and need is known as market orientation or market orientation. A good market orientation of an MSME will contribute to the implementation of a good marketing strategy by the management (Abreu Pederzini, 2016). This will certainly have an impact on the level of effectiveness of MSME performance. The performance of MSMEs will get better along with the better orientation of MSMEs in the target market.

Despite having good prospects and great potential for contribution, the process of digitizing MSMEs in Indonesia is still facing various problems at the grassroots level, for example, the lack of knowledge of business owners about technology, the marketing process still focus on conventional marketing, and the inaccessibility ofinternet facilities in locations, business, etc (Soni et al., 2021). The main essence of the $\mathrm{O} 2 \mathrm{O}$ model is to provide information, services, offer discounts and so on as a message from the outlet through the $\mathrm{O} 2 \mathrm{O}$ platform to encourage online users to come to the outlet, thus, it can be said that $\mathrm{O} 2 \mathrm{O}$ is the process of a consumer buying goods and services online; then go to a store or outlet to enjoy the service. Based on the description above, this study aims to examine the influence of digital literacy and market orientation on MSME performance mediated by E-commerce adoption with $\mathrm{O} 2 \mathrm{O}$ Business as a Moderating variable.

\section{Literature Review}

SME Performance (Y) 
Kitchot et al.,( 2021) states that the performance of MSMEs is the result of work achieved by an individualand can be completed with the individual's tasks within the company and within a certain period, and will be linked to the size of the value or standard of the company that the individual works for. MSMEs that have good performance can become stronger to become the backbone of the economy and will play an increasingly important role in the national economy. Micro business itself is defined as a productive business owned by individuals or individual business entities that meet the criteria for micro businesses that have been regulated in the law (Charoensukmongkol, P., \& Sasatanun, 2017b). With the criteria for assets that amount to a maximum of Rp50 million, the criteria of a maximum turnover of Rp300 million per year. The successful performance of an MSME can be measured through the following indicators (Herman, H., Hady, H., \& Arafah, 2018) SME Performance can be identified with the dimensions as the following: Financial performance, supported bythe indicators sales growth and product profit, Customer Satisfaction, supported by the indicators: customer satisfaction, customer complain and Perceived Product Quality, Supported by the indicators successful Transaction.

In general, what is meant by digital literacy is the ability to use information and communication technology(ICT) to find, evaluate, utilize, create, and communicate content/information, with both cognitive and technical skills Mihailidis, 2015 argues that digital literacy is the ability to understand and use information in various formats that come from various digital sources that are displayed through computers (Clauss et al., 2021). The rapid development of digital media provides opportunities, such as increasing e-commerce business opportunities, the birth of new digital mediabased jobs, and the development of literacy skills without negating print-based text. Furthermore, Monteiro, A., \& Leite, (2021) argues that digital literacy consists of four main dimensions that must be mastered, namely basic abilities (underpinning), background knowledge of information (background knowledge), main competencies (central competencies), attitudes and perspectives (attitudes and perspectives). Digital Literacy can be identified with the dimensions (1) Cognitive in ability to analyze background information and evaluate information (2) Social such as help the poverty entrepreneur use digital technology (3)Technical in knowledge of how web browser work and ability use search engine. Market Orientation (X2)

Market orientation as the most effective and efficient organizational culture to create the behaviors needed to create superior value for buyers and produce superior performance for the company (Mahmoud et al., 2016a). Companies that have made market orientation their organizationalculture will be based on external basic needs, market wants and demands as the basis for formulating strategies for each business unit within the organization, and determining the company's success.

With this information, the selling company will understand who its potential customers are now and in the future and what they want now and in the future (Leal-Rodríguez, A. L., \& Albort-Morant, 2016). Market Orientation can be identified with the dimensions (1) Customer orientation, supported by ability to shifting organizational values, beliefs, assumption and premises toward a two-way relationship between customers and the firm (2) Competitor orientation, supported by the indicators ability sellers have an understanding of the short term strengthand weak-ness and an understanding of long-term capabilities (3) Technical, Supported by indicators how a business utilizes its resources to create superior value for its target customer.

E-Commerce Adoption (Z)

E-Commerce is often also called market-making because of its existence that can directly form a market incyberspace that can bring together sellers and buyers from various places in the world through internet access. (Tian et al., 2018) developed a method called the environmental organizational technical framework (TOE). This framework is similar to the DOI framework and has 3 sections within this framework: (i) the technical context;

(ii) the characteristics of the internal and external technology associated with the company (Macchion et al., 2017)

(iii) organizational context: descriptive measures, eg organizational size, capital, etc.; TOE is common because the diffusion of the Innovation Framework is consistent (Mahmoud et al, 2016b). Electronic commerce (EC) is the useof the Internet and intranets to buy, sell, transport, or trade data, goods or services. In other words, the dimensions of e-commerce, namely: 1) Trade via the internet and intranets; 2) Trading through internet web facilities; and 3)Trading through data exchange systems.

E-Commerce Adoption It can be identified with the dimensions (1) Individual, supported by owner's 
innovativeness, IT ability and IT experiences (2) Technology supported by perceived ease of use, technological and compatibility (3) Environment supported by indicators of customer \& competitor pressure, external driver.

O2O (Online-to-Offline) (M)

Online-to-offline $(\mathrm{O} 2 \mathrm{O})$ is one of the newest e-commerce business models that uniquely combines the benefits of online and offline modes to help businesses achieve increased customer reach, greater market share, and expanded marketing capabilities, among other improvements (Kang et al.,2021). It is defined as "e-commerce that combines searching and ordering products or services online, and consumption in physical stores" (Wan, X., \& Chen, 2019) Online-to-Offline refers to the combination of offline business and online commerce (Kang et al.,2021). The $\mathrm{O} 2 \mathrm{O}$ model is characterized by online information flow and cash flow, while offline logistics and trade flows can broaden the scope of ecommerce business. The main essence of the $\mathrm{O} 2 \mathrm{O}$ model is to provide information, services, offer discounts, etc. as a message from the outlet through the $\mathrm{O} 2 \mathrm{O}$ platform to encourage online users to come to the outlet, thus, it can be said that $\mathrm{O} 2 \mathrm{O}$ is the process of a consumer buying goods and services online; then go the store or outlet to enjoy the service (Sam Liu, C. H., \& Huang, 2020).

The theory further states that the level of adoption is influenced by five attributes namely relative advantage, complexity, suitability, observability, and the ability to try. The DOI model also categorizes adopters into innovators, early adopters, early majority, late majority and laggards (Sarkar, 2008). O2O Business Adoption can be identified with the dimensions (1) Relative advantage, supported by indicator market development, customer base (2) Compatibility that supported by compatible current business, knowledge and organizational behavior (3) Trialability that supported by exploration easiness and correcting mistakes.

\section{Research Method}

This study aims to determine the effect of digital literacy and market orientation on MSME performance mediated by E-commerce adoption with $\mathrm{O} 2 \mathrm{O}$ Business as a Moderating variable. The design hypothesis in this study is shown in the following figure.

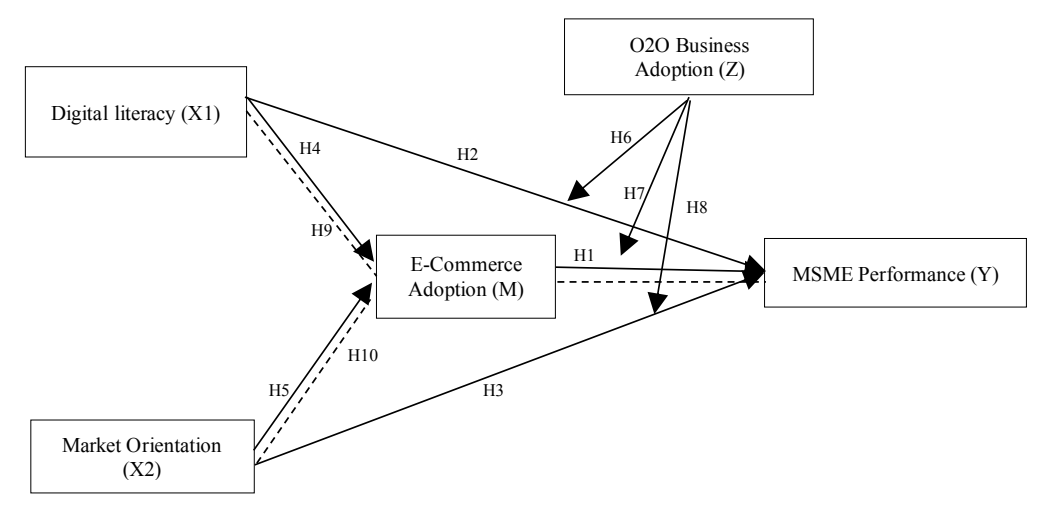

Figure 1. The design hypothesis

(Source: Adusted by Researcher, 2021)

Information:

Indirect Effect
Direct Effect

Direct Effect

H1 Effect of E-Commerce Adoption on MSME Performance

H2 Effect of Digital Literacy on MSME Performance

H3 Effect of Market Orientation on MSME Performance

H4 Effect of Digital Literacy on E-Commerce Adoption 
H5 Effect of Market Orientation on E-Commerce Adoption

H6 Effect of Digital Literacy on MSME Performance Moderated by O2O Business Adoption

H7 Effect of Market Orientation on MSME Performance Moderated by O2O Business Adoption

H8 Effect of E-Commerce Adoption on MSME Performance Moderated by O2O Business Adoption

Indirect Effect

H9 Effect of Digital Literacy on MSME Performance Mediated by E-Commerce Adoption

H10 Effect of Market Orientation on MSME Performance Mediated by E-Commerce Adoption The research approach used in this study is a quantitative approach. Quantitative research methods aim to test the established hypotheses. The quantitative method is in the form of numbers derived from measurements usinga scale on the variables in the study. The population in this study is all MSMEs that have collaborated with E-Commerce. The sample in this study was obtained using a quota sampling technique, which only limited data acquisition to 100 MSMEs of E-Commerce partners (Dvorkina et al., 2020). Data analysis used the structural approach of the Equation Model (SEM) assisted by the smart PLS application (Civelek, 2018) The research procedures in this research are described in the following.

1. Reflective Measurement Model Evaluation

The measurement model or outer model with reflexive indicators is evaluated with convergent and discriminant validity of the indicators and composite reliability for indicator blocks. It is carried out to ensure that the measurement used is feasible to be utilized as a measurement (valid and reliable). Therefore, this evaluation analyzes the validity and reliability, and sees the level of prediction of each indicator on the latent variable by analyzing the following.

Table 1. Instrument Testing

\begin{tabular}{lll}
\hline Instrument Test & Test Used \\
\hline 1. & Validity Test & 1. Convergent Validity \\
& & 2. AVE \\
2. & Reliability & 3. Cronbach Alpha \\
Test & & 4. Composite Relibility \\
\hline
\end{tabular}

Source: Adusted by Researcher, 2021

2. Designing a Structural Model (Inner Model) and Measurement (Outer Model)

Inner model or also called structural model, inner relation, and substantive theory functions to describe the relationship between latent variables based on substantive theory.

3. Structural Model Evaluation

The structural model or inner model is carried out to ensure that the structural model built is robust and accurate. This model is evaluated using R-square for the dependent construct. This test aims to explain the large proportion of variation in dependent variable that can be explained by all independent variables. The interpretation is that changes in the R-square value are used to assess the effect of certain independent latent variables on the dependent latent variable whether it has a substantive effect.

\section{Research Result}

Based on the results of testing the validity of the instrument, it is known that there are 29 indicators measured. 
1. Reliability Test Result

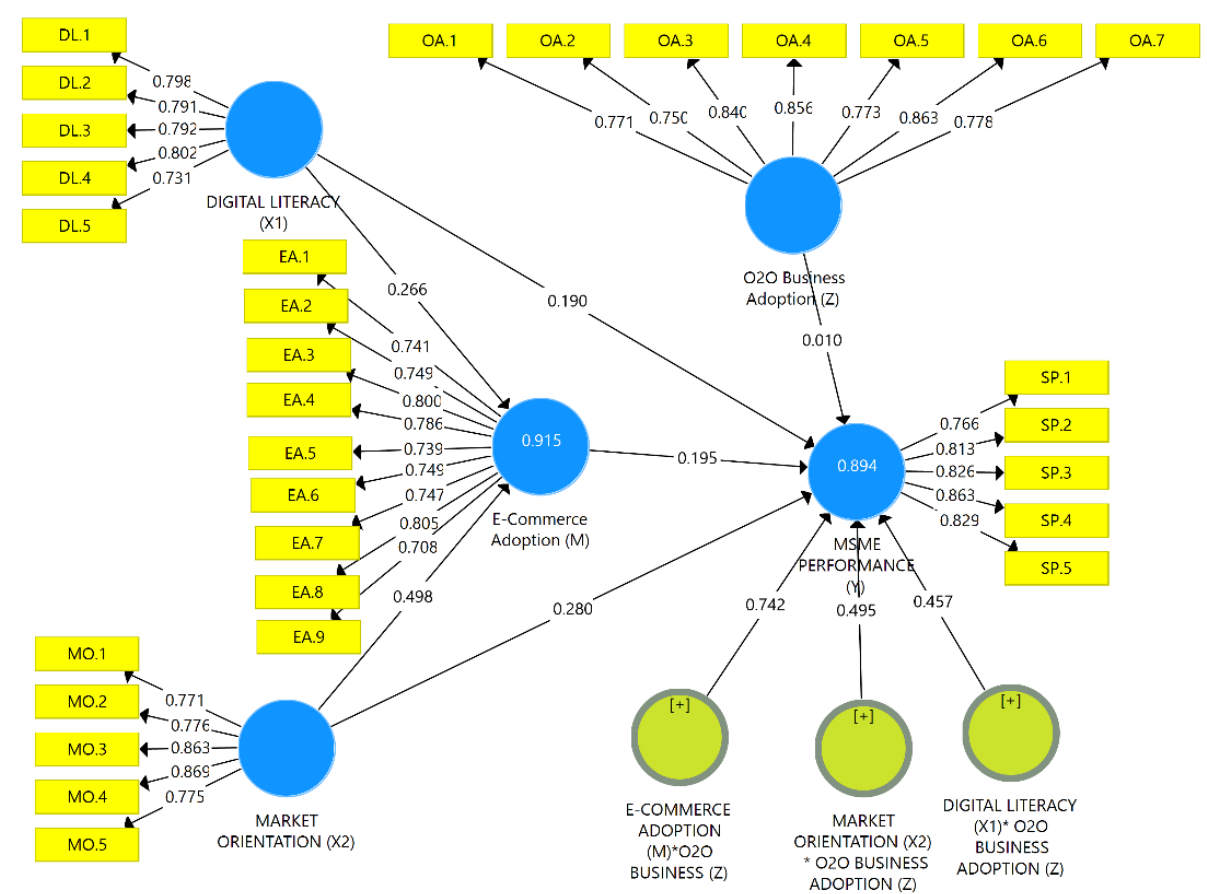

Figure 2. Outer Model Analysis

(Sources: Primary Data, Processed with SmartPLS, 2021)

Table 2. Reliability Test Result

\begin{tabular}{|c|c|c|c|}
\hline Variable & Cronbach Alpha & CompositeReliability & Information \\
\hline Digital Literacy (X1) & 0,842 & 0,888 & Reliable \\
\hline Market Orientation (X2) & 0,870 & 0,906 & Reliable \\
\hline E-Commerce Adoption (Z) & 0,908 & 0,924 & Reliable \\
\hline O2O Business Adoption (M) & 0,909 & 0,928 & Reliable \\
\hline MSME Performance (Y) & 0,878 & 0,911 & Reliable \\
\hline
\end{tabular}

The test results show that all instruments are declared reliable with a Cronbach Alpha score and Compositereliability of $>0.7$.

2. R-Square Test

Table 3. R-Square Test Result

\begin{tabular}{ccc}
\hline Variables & R Square & R Square Adjusted \\
\hline E-Commerce Adoption (Z) & 0,915 & 0,913 \\
MSME Performance (Y) & 0,894 & 0,885 \\
\hline
\end{tabular}

Based on the test results, obtained a score of R-Square for e-commerce adoption (z) of 0,915 which means e- commerce adoption influenced by digital literacy (X1) and market orientation (X2) of 91.5\% and $8.5 \%$ others areinfluenced by variables that have not been explained in this study. Score of RSquare for MSME Performance is equal to 0,894 which means digital literacy (X1) and market orientation (X2) and O2O business adoption (M) affect MSME Performance (Y) by 89.4\% and the other $10.6 \%$ influenced by other variables that have not been explained in this study. 
Inner Model Analysis

Testing the hypothesis can be seen through the value of t-statistics and probability values. The hypothesis testing uses statistical values, for alpha $5 \%$ by comparing t-count with $t$-table. Thus, the criteria for accepting or rejecting the hypothesis are $\mathrm{HO}$ is rejected if t-statistic $>\mathrm{t}$-count. To reject/accept the hypothesis, it uses probability; in which Ha is accepted if the $p$ value $<0.05$.

Table 4. Hypothesis Test Result

\begin{tabular}{|c|c|c|c|c|}
\hline \multicolumn{2}{|r|}{ Direct Effect } & \multirow{2}{*}{$\frac{\text { Beta }}{0,195}$} & \multirow{2}{*}{$\frac{t \text {-count }}{, 783}$} & \multirow{2}{*}{$\begin{array}{c}\text { P- } \\
\text { Values }\end{array}$} \\
\hline$\overline{\mathrm{H} 1}$ & Effect of E-Commerce Adoption on MSME Performance & & & \\
\hline $\mathrm{H} 2$ & Effect of Digital Literacy on MSME Performance & 0,190 & 2,012 & 0,045 \\
\hline $\mathrm{H} 3$ & Effect of Market Orientation on MSME Performance & 0,280 & 2,436 & 0,020 \\
\hline $\mathrm{H} 4$ & Effect of Digital Literacy on E-Commerce Adoption & 0,266 & 2,214 & 0,027 \\
\hline H5 & Effect of Market Orientation on E-Commerce Adoption & 0,498 & 3,780 & 0,000 \\
\hline $\begin{array}{l}\text { H6 } \\
\text { by } \mathrm{C}\end{array}$ & \multicolumn{2}{|c|}{$\begin{array}{l}\text { Effect of Digital Literacy on MSME Performance Moderated0,457 } \\
\text { Business Adoption }\end{array}$} & 6,372 & 0,000 \\
\hline $\begin{array}{l}\text { H7 } \\
\text { Moc }\end{array}$ & \multicolumn{2}{|c|}{$\begin{array}{l}\text { Effect of E-Commerce Adoption on MSME Performance } 0,742 \\
\text { ted by } \mathrm{O} 2 \mathrm{O} \text { Business Adoption }\end{array}$} & 5,386 & 0,000 \\
\hline $\begin{array}{l}\mathrm{H} 8 \\
\text { mod } \\
\text { Indi }\end{array}$ & \multicolumn{2}{|c|}{ Effect of Market Orientation on MSME Performance0,495 } & 5,113 & 0,001 \\
\hline $\begin{array}{l}\text { H9 } \\
\text { Bus }\end{array}$ & \multicolumn{2}{|c|}{$\begin{array}{l}\text { Effect of Digital Literacy on MSME Performance Mediated by } 0,044 \\
\text { s Adoption }\end{array}$} & 0,609 & 0,543 \\
\hline $\begin{array}{l}\mathrm{H} 10 \\
\text { by } \mathrm{B}\end{array}$ & \multicolumn{2}{|c|}{$\begin{array}{l}\text { Effect of Market Orientation on MSME Performance Mediated0,124 } \\
\text { ness Adoption }\end{array}$} & 2,974 & 0,003 \\
\hline
\end{tabular}

\section{H1: E-Commerce Adoption Affects MSME Performance}

The results of hypothesis testing have an influence between e-commerce adoption on MSME performance, it is shown that the p-value is 0,039 which is smaller than 0.05 . In addition, the t-statistic value is 2,783 , which isgreater than t table (1.98) and the beta score is positif $(0,195)$. Thus, from the explanation above, it will show that. E-commerce adoption has a significant positive effect on MSME performance. E-commerce adoption is a mediator between globalization and corporate performance Therefore, the adoption of E-commerce can improve the performance ofMSMEs. This is in line with research by (Cassia, F., \& Magno, 2021) which states that e-commerce adoption has a significant positive effect on MSME performance.

\section{H2: Digital Literacy Affects MSME Performance}

The results of hypothesis testing have an influence between digital literacy on MSME performance, it is shown that the p-value value is 0.045 , which is smaller than 0.05 . In addition, the t-statistic value is 2,012 which is greater than t-table (1.98) and the beta score is positive 0.190). Thus, from the explanation above, it will show that Digital Literacy has a significant positive effect on MSME performance. MSME performance can be interpreted as the ability of a business to achieve its goals through efficient and effective use of resources and describes how far a business has achieved its results after being compared with previous performance, previous performance and other organizational benchmarking performance, as well as to what extent it has achieved the goals and targets that have been set. Thus, from the results of this study it can be seen that the presence of digital literacy can improve the performance of SMEs. This is in line with research by (Abubakari et al., 2021; Ollerenshaw et al., 2021) who states that digital literacy has an influence on MSME performance.

\section{H3: Market Orientation Affects MSME Performance}

The results of testing the hypothesis that there is an influence between Market Orientation on MSME Performance, it is shown that the $\mathrm{p}$-value is 0,020 , which is smaller than 0.05 . And the $\mathrm{t}$-statistic value is 2,436 , which is greater than t-table (1.98) and the beta score is 0.280 . Thus, from the explanation above, it will show that Market Orientation has a significant positive effect on MSME Performance. Market orientation is a valuable organizational culture in helping to grow a company to follow the market so as to offer greater value to customers, which is the key to corporate action. So that market orientation does affect the performance of MSMEs. This is inline with research by (Tjahjadi et al., 
2020)who states that market orientation has effect on MSME performance.

\section{H4: Digital Literacy Affects E-Commerce Adoption}

The results of hypothesis testing have an influence between digital literacy on e-commerce adoption, it is shown that the p-value is 0,027 , which is smaller than 0.05 . In addition, the t-statistic value is 2,214 , which is greater than $\mathrm{t}$-tabel (1.98) and the beta score is positif 0,266 . Thus, from the explanation above, it will show that digital literacy has a significant positive effect on e-commerce adoption. E-commerce adoption is all business activities carried out online using internet-based information technology. Therefore, the greater the value of digital literacy, the greater the e-commerce adoption is. This is in line with research by (Ariansyah et al., 2021; Elhajjar, S., \& Ouaida, 2020) that states that digital literacy has an influence on e-commerce adoption.

\section{H5: Market Orientation Affects E-Commerce Adoption}

The results of testing the hypothesis that there is an influence between Market Orientation on ECommerceAdoption, it is shown that the p-value is 0,000 , which is smaller than 0.05 . And the t-statistic value is 5,747, whichis greater than 1.98 and the beta score is 0,498 . So, from the explanation above, it will show that market orientation has a significant positive effect on e-commerce adoption. Orientation in marketing management includes production, product, market and holistic marketing orientation. Therefore, E-Commerce Adoption very much needed to improve Market Orientation in holistic marketing. This is in line with research by (Bamfo, B. A., \& Kraa, 2019; Herrero et al., 2018)which states that market orientation has an effect on e-commerce adoption.

\section{H6: Digital Literacy Affects MSME Performance Moderated by O2O Business Adoption}

The results of testing the hypothesis that there is an influence between Digital Literacy on MSME Performance and $\mathrm{O} 2 \mathrm{O}$ Business Adoption as moderator, it is shown that the p-value is 0.000 , which is smaller than 0.05 . In addition, the $t$-statistic value is 6.372 which is greater than 1.960 and the beta score is 0.457 . Thus, from the explanation above, it will show that Digital Literacy has a significant positive effect on MSME Performance which is moderated by O2O Business Adoption. Therefore, it is known that the presence of $\mathrm{O} 2 \mathrm{O}$ Business Adoption as a moderator increases the influence of Digital Literacy on MSME Performance. This is in line with research by (Gregory et al., 2016) which states that the adoption of $\mathrm{O} 2 \mathrm{O}$ business as a moderator increases the influence of digital literacy on MSME performance.

\section{H7: E-Commerce Adoption Affects MSME Performance Moderated by O2O Business Adoption}

The results of testing the hypothesis that there is an influence between e-commerce adoption on MSME performance and $\mathrm{O} 2 \mathrm{O}$ business adoption as moderator, it is shown that the p-value is $\mathbf{0 . 0 0 0}$, which is smaller than 0.05 . In addition, the t-statistic value is 5.386, which is greater than 1.98 and the beta score is 0.742 . Thus, from the explanation above, it will show that e-commerce adoption has a significant positive effect on MSME performance which is moderated by $\mathrm{O} 2 \mathrm{O}$ business adoption. Therefore, it is known that the adoption of $\mathrm{O} 2 \mathrm{O}$ business as a moderator strengthens the influence of e-commerce adoption on MSME performance. This is in linewith research by (Wang et al., 2020)which states that the adoption of $\mathrm{O} 2 \mathrm{O}$ business as a moderator strengthens the effect of e-commerce adoption on MSME performance.

\section{H8: Market Orientation Affects MSME Performance Moderated by O2O Business Adoption}

The results of testing the hypothesis that there is an influence between market orientation on MSME performance and $\mathrm{O} 2 \mathrm{O}$ business adoption as moderator, it is shown that the p-value is 0,001 , which is smaller than 0.05 . In addition, the t-statistic value is 5,113 , which is greater than 1.98 and the beta score is 0.495 . Thus, from the explanation above, it will show that Market Orientation has a significant positive effect on MSME Performance which is moderated by $\mathrm{O} 2 \mathrm{O}$ Business Adoption. Thus, it is known that the presence of $\mathrm{O} 2 \mathrm{O}$ Business Adoption as a moderator increases the influence of Market Orientation on MSME Performance. This is in line with research by (Gregory et al., 2016; (Tsai et al., 2015) which states that the adoption of $\mathrm{O} 2 \mathrm{O}$ business as a moderator strengthens the influence of market orientation on MSME performance.

H9: E-Commerce Adoption does not Mediate Digital literacy on MSME Performance

According to the calculation results, it is known that e-commerce adoption is not able to mediate the 
relationship between Digital literacy and MSME performance with a positive score (0.044), t-count $<$ t-table $(0.6<1.98)$, and $p$-values of $>0.05(0.543)$. On average, MSMEs that show good performance have been able to adapt their business. The results of this study also support the findings by (Carlson et al., 2012). Digital literacy has met the challenges of e-commerce adoption. With digital literacy, MSMEs are sure to be able to adapt their business, especially in terms of promotion which is the main activity that supports sales. One of them is through the use of social media. With good promotion through the application of digital literacy, MSMEs is able to meet sales targets, especially in this current situation, Indonesians are social media literate, which then makes it easier for MSMEs to carry out promotional activities so that with or without E-Commerce Adoption, if MSMEs have been able to carry out digital literacy, MSMEs will be able to improve their performance.

H10: E-Commerce Adoption Mediates Market Orientation on MSME Performance

According to the calculation results, it is known that e-commerce adoption is able to mediate the relationship between market orientation and MSME performance with a positive score $(0.124), t$-count $>\mathrm{t}$-table $(2.97>1.98)$, and $\mathrm{p}$-values of $>0.05(0.003)$. Market orientation is a view, perspective, or culture seen from a company's processes and activities in creating the high est value for customer needs and desires as the core of the marketing process, namely focusing on customer satisfaction. Market orientation, which is strengthened by good business adaptation, is able to support the performance of MSMEs. With good business adaptation, MSMEs are able to develop and understand better what consumers need so that they can create customer value and market strategies with information on competitors' strengths and weaknesses.

\section{Conclusion}

From the results of the research and discussion above, it can be concluded that Digital Literacy has a significant positive effect on E-Commerce Adoption, Digital Literacy has a significant positive effect on MSMEPerformance, E-Commerce Adoption has a significant positive effect on Performance MSMEs. Market Orientation has a significant positive effect on E-Commerce Adoption. Market orientation has a significant positive effect on MSME performance. O2O Business Adoption has a significant positive effect on MSME Performance. Digital Literacy has a significant positive effect on MSME Performance, moderated by $\mathrm{O} 2 \mathrm{O}$ Business Adoption. MarketOrientation e-commerce adoption has a significant positive effect on MSME performance which is moderated by $\mathrm{O} 2 \mathrm{O}$ business adoption. ECommerce adoption has a significant positive effect on the performance of MSMEs moderated by $\mathrm{O} 2 \mathrm{O}$ Business Adoption. Market orientation and digital literacy are important factors in the success of an MSME to survive in an ever-fluctuating economic condition. Understanding of market orientation and digital literacy in running a business can have an impact on customer satisfaction which then has an impact on improving MSME performance. Digital literacy and market orientation are two factors that affect the performance of MSMEs. The performance of MSMEs will be more significant when MSMEs are able to take advantage of e-commerce properly. Even, it is recommended for MSME actors to be able to implement an Online to Offline system that allows people to shop online but can pay, take, return offline, and can even buy online at offline stores. In addition, MSMEs that use the $\mathrm{O} 2 \mathrm{O}$ network are able to develop their business and provide the best satisfaction for consumers.

\section{References}

Abbad, M., Magboul, I. H. M., \& AlQeisi, K. (2021). Determinants and outcomes ofe-business adoption among manufacturing SMEs: Insights from a developing country. Journal of Science and Technology Policy Management. https://doi.org/10.1108/JSTPM-03-2021-0049

Abbasi, K., Alam, A., Du, M. (Anna), \& Huynh, T. L. D. (2021). FinTech, SME efficiency and national culture: Evidence from OECD countries. Technological Forecasting and Social Change. https://doi.org/10.1016/j.techfore.2020.120454

Abreu Pederzini, G. D. (2016). Strategic management cultures: historical connections with science. Journal of Management History. https://doi.org/10.1108/JMH-12-2015-0212

Abubakari, A., Ofori, K. S., Boateng, H., N'Da, K., \& Hinson, R. E. (2021). The effect of foreign market knowledge on SME export performance: a study ofnon-traditional SMEs in Ghana. Global Knowledge, Memory and Communication. https://doi.org/10.1108/GKMC-03-2021- 
0054

Al-Somali, S. A., Gholami, R., \& Clegg, B. (2015). A stage-oriented model (SOM) for e-commerce adoption: A study of Saudi Arabian organisations. Journal of Manufacturing Technology Management. https://doi.org/10.1108/JMTM-03-2013-0019

Alharbi, R. K., Yahya, S. Bin, \& Kassim, S. (2021). Impact of religiosity and branding on SMEs performance: does financial literacy play a role? Journal of Islamic Marketing. https://doi.org/10.1108/JIMA-08-2019- 0162

Anand, S., \& Rao, A. B. (2016). Models for Deployment of Solar PV Lighting Applications in Rural India. Energy Procedia. https://doi.org/10.1016/j.egypro.2016.11.212

Ariansyah, K., Sirait, E. R. E., Nugroho, B. A., \& Suryanegara, M. (2021). Drivers of and barriers to ecommerce adoption in Indonesia: Individuals' perspectives and the implications. Telecommunications Policy. https://doi.org/10.1016/j.telpol.2021.102219

Bamfo, B. A., \& Kraa, J. J. (2019). Market orientation and performance of small and medium enterprises in Ghana: The mediating role of innovation. Cogent Business and Management. https://doi.org/10.1080/23311975.2019.1605703

Cassia, F., \& Magno, F. (2021). Cross-border e-commerce as a foreign market entry mode among SMEs: the relationship between export capabilities and performance. Review of International Business and Strategy. https://doi.org/10.1108/RIBS-02-2021-0027

Charoensukmongkol, P., \& Sasatanun, P. (2017). Social media use for CRM and business performance satisfaction: The moderating roles of social skills and social media sales intensity. Asia Pacific Management Review. https://doi.org/10.1016/j.apmrv.2016.10.005

Chuang, S. H. (2018). Facilitating the chain of market orientation to value co-creation: The mediating role of e- marketing adoption. Journal of Destination Marketing and Management. https://doi.org/10.1016/j.jdmm.2016.08.007

Civelek, M. E. (2018). Essentials of Structural Equation Modeling. Zea Books. https://doi.org/10.13014/k2sj1hr5 Clauss, T., Abebe, M., Tangpong, C., \& Hock, M. (2021). Strategic Agility, Business Model Innovation, and Firm Performance: An Empirical Investigation. IEEE Transactions on Engineering Management.

https://doi.org/10.1109/TEM.2019.2910381

Dvorkina, T., Bzikadze, A. V., \& Pevzner, P. A. (2020). The string decomposition problem and its applications to centromere analysis and assembly. Bioinformatics. https://doi.org/10.1093/BIOINFORMATICS/BTAA454 Elhajjar, S., \& Ouaida, F. (2020). An analysis of factors affecting mobile banking adoption. International Journal

of Bank Marketing. https://doi.org/10.1108/IJBM-02-2019-0055

Gilster, M. E., Kleinschmit, J. L., Cummings, S. P., \& Ronnenberg, M. M. (2020). Teaching NotePick Your Platform: Social Media Advocacy Skill Building. Journal of Social Work Education. https://doi.org/10.1080/10437797.2019.1593903

Gregory, K., Sean, T., Wang, J., Zhang, X. X., Cao, Q., Tjosvold, D., ... ZHOU, J. (2016). Rethinking "Top- Down" and "Bottom-Up" Roles of Top and Middle Managers in Organizaional Chagne. Leadership Quarterly.

Gunawan, M., Asyahira, R., \& M Sidjabat, F. (2020). Environmental Management System Implementation in MSMEs: A Literature Review. Jurnal Serambi Engineering. https://doi.org/10.32672/jse.v5i2.1958

Herman, H., Hady, H., \& Arafah, W. (2018). The Influence of Market Orientation and Product Innovation on theCompetitive Advantage and Its Implication toward Small and Medium Enterprises (Ukm) Performance.International Journal of Science and Engineering Invention. https://doi.org/10.23958/ijsei/vol04-i08/02

Herrero, A., San Martín, H., \& Collado, J. (2018). Market orientation and SNS adoption for marketing purposes

in hospitality microenterprises. Journal of Hospitality and Tourism Management. https://doi.org/10.1016/j.jhtm.2017.11.005

Hill, H. (2018). Asia's Third Giant: A Survey of the Indonesian Economy. Economic Record. https://doi.org/10.1111/1475-4932.12439 
Iborra, M., Safón, V., \& Dolz, C. (2020). What explains the resilience of SMEs? Ambidexterity capability and strategic consistency. Long Range Planning. https://doi.org/10.1016/j.lrp.2019.101947

Kang, M. J., Wu, Z., \& Hwang, H. J. (2021). A Study on the Mediating Effect of Customer Orientation between O2O Service Quality and Customers' Perceived Service Satisfaction. Journal of Distribution Science. https://doi.org/10.15722/jds.19.2.202102.37

Kitchot, S., Siengthai, S., \& Sukhotu, V. (2021). The mediating effects of HRM practices on the relationship between SCM and SMEs firm performance in Thailand. Supply Chain Management. https://doi.org/10.1108/SCM-05-2019-0177

Latorre, F., Guest, D., Ramos, J., Gracia, F. J., Nishanthi, H. M., Kailasapathy, P., ... Benson, J. (2013). 済無No

Title No Title. Strategic Management Journal.

Leal-Rodríguez, A. L., \& Albort-Morant, G. (2016). Linking market orientation, innovation and performance: An empirical study on small industrial enterprises in Spain. Journal of Small Business Strategy.

Lin, O. C. C. (2018). Innovation and entrepreneurship: Choice and challenge. In Innovation and Entrepreneurship: Choice and Challenge. https://doi.org/10.1142/10195

Macchion, L., Moretto, A. M., Caniato, F., Caridi, M., Danese, P., \& Vinelli, A. (2017). International ecommerce for fashion products: what is the relationship with performance? International Journal of Retail and Distribution Management. https://doi.org/10.1108/IJRDM-11-2015-0171

Mahmoud, M. A., Blankson, C., Owusu-Frimpong, N., Nwankwo, S., \& Trang, T. P. (2016). Market orientation, learning orientation and business performance: The mediating role of innovation. International Journal of Bank Marketing. https://doi.org/10.1108/IJBM-04-2015-0057

Masa'deh, R., Al-Henzab, J., Tarhini, A., \& Obeidat, B. Y. (2018). The associations among market orientation, technology orientation, entrepreneurial orientation and organizational performance. Benchmarking. https://doi.org/10.1108/BIJ-02-2017-0024

Mihailidis, P. (2015). Digital curation and digital literacy: Evaluating the role of curation in developing critical literacies for participation in digital culture. E-Learning and Digital Media. https://doi.org/10.1177/2042753016631868

Mohammadyari, S., \& Singh, H. (2015). Understanding the effect of e-learning on individual performance: The role of digital literacy. Computers and Education. https://doi.org/10.1016/j.compedu.2014.10.025

Monteiro, A., \& Leite, C. (2021). Digital literacies in higher education: Skills, uses, opportunities and obstacles to digital transformation. Revista de Educación a Distancia (RED). https://doi.org/10.6018/red.438721 Ollerenshaw, A., Corbett, J., \& Thompson, H. (2021). Increasing the digital literacy skills of regional SMEs through high-speed broadband access. Small Enterprise Research. https://doi.org/10.1080/13215906.2021.1919913

Oyewobi, L. O., Adedayo, O. F., Olorunyomi, S. O., \& Jimoh, R. (2021). Social media adoption and business performance: the mediating role of organizational learning capability (OLC). Journal of Facilities Management. https://doi.org/10.1108/JFM-12-2020-0099

Sam Liu, C. H., \& Huang, C. E. (2020). Discovering differences in the relationship among social entrepreneurial orientation, extensions to market orientation and value co-creation - The moderating role of social entrepreneurial self-efficacy. Journal of Hospitality and Tourism Management. https://doi.org/10.1016/j.jhtm.2019.12.002

Saridakis, G., Lai, Y., Mohammed, A. M., \& Hansen, J. M. (2018). Industry characteristics, stages of E-commercecommunications, and entrepreneurs and SMEs revenue growth. Technological Forecasting and Social Change. https://doi.org/10.1016/j.techfore.2017.10.017

Sarkar, A. (2008). E-Commerce Adoption and Implementation in SMEs: An Analysis of Factors. 21 St Annual Conference of the National Advisory Committee on Computing Qualifications (NACCQ 2008).

Shen, C. wen, Min Chen, \& Wang, C. chen. (2019). Analyzing the trend of O2O commerce by bilingual text mining on social media. Computers in Human Behavior. 120 
https://doi.org/10.1016/j.chb.2018.09.031

Soejachmoen, M. P. (2016). Financial Inclusion in Indonesia: Moving Towards a Digital Payment System. In

Financial Inclusion in Asia. https://doi.org/10.1057/978-1-137-58337-6_5

Soni, G., Mangla, S. K., Singh, P., Dey, B. L., \& Dora, M. (2021). Technological interventions in social business: Mapping current research and establishing future research agenda. Technological Forecasting and Social Change. https://doi.org/10.1016/j.techfore.2021.120818

Srhoj, S., Lapinski, M., \& Walde, J. (2020). Impact evaluation of business development grants on SME performance. Small Business Economics. https://doi.org/10.1007/s11187-020-00348-6

Tayibnapis, A. Z., Wuryaningsih, L. E., \& Gora, R. (2021). Medium, Small and Medium Enterprises and Digital Platforms. South Asian Journal of Social Studies and Economics. https://doi.org/10.9734/sajsse/2021/v10i230258

Tian, L., Vakharia, A. J., Tan, Y. (Ricky), \& Xu, Y. (2018). Marketplace, Reseller, or Hybrid: Strategic Analysis of an Emerging E-Commerce Model. Production and Operations Management. https://doi.org/10.1111/poms.12885

Tjahjadi, B., Soewarno, N., Nadyaningrum, V., \& Aminy, A. (2020). Human capital readiness and global market orientation in Indonesian Micro-, Small- and-Medium-sized Enterprises business performance. International Journal of Productivity and Performance Management. https://doi.org/10.1108/IJPPM-04-2020-0181

Tsai, T. M., Wang, W. N., Lin, Y. T., \& Choub, S. C. (2015). An O2O Commerce Service Framework and its Effectiveness Analysis with Application to Proximity Commerce. Procedia Manufacturing. https://doi.org/10.1016/j.promfg.2015.07.668

TUC \&\&childer ENgland. (2016). An introduction to child protection legislation in the UK. In Journal of HumanDevelopment and Capabilities.

Wan, X., \& Chen, J. (2019). The relationship between platform choice and supplier's efficiencyevidence from China's online to offline (O2O)e-commerce platforms. Electronic Markets, 29(2), 153-166. https://doi.org/10.1007/s12525-017-0280-3

Wang, O., Somogyi, S., \& Charlebois, S. (2020). Food choice in the e-commerce era : A comparison between business-to-consumer (B2C), online-to-offline $(\mathrm{O} 2 \mathrm{O})$ and new retail. British Food Journal. https://doi.org/10.1108/BFJ-09-201 